\title{
Runas verbu semantiskā saistāmība oriğināltekstā un tulkojumā
}

\section{Semantic relatedness of speech verbs in an original text and its translation}

\author{
Svetlana Polkovņikova \\ Daugavpils Universitāte, Humanitārā fakultāte \\ Latviešu valodas katedra \\ Vienības iela 13, Daugavpils, LV-5401 \\ E-pasts: svetlana.polkovnikova@du.lv
}

\begin{abstract}
Zinātniskā pētījuma problēmas izvēle ir saistīta ar runas verbu semantisko īpatnību un saistāmības jautājumu izpētes aktualitāti latviešu valodniecībā. Šādu pētījumu aizsākumi meklējami 20. gs. 80. gados Intas Freimanes darbos, kuros izteikts rosinājums pievērsties runas verbu vispusīgai izpētei.
\end{abstract}

Verba nozīmīgā un organizējošā loma teikuma semantiskajā struktūrā un valodas sistēmā kopumā nav apšaubāma. Lingvistiskajā literatūrā bieži vien ir akcentēts, ka verba semantisko struktūru raksturo ietilpība, plašums un elastība, kas arī nosaka verba sintaktiskās potences. Verba nozīmes jēdziens nav atdalāms no verba spējas saistīties ar citiem vārdiem, turklāt vārdiem ar līdzịgu vai vienādu semantiku piemīt gan kopīgas semantiskās pazīmes, gan tipisks saistījums un funkcionēšana.

Mūsdienu lingvistikā interesei par verba valences jautājumiem ir vairāki cēloṇi. No vienas puses, tas ir saistīts ar leksikalizētās gramatikas un komplekso vārdnīcu izveidi, kurās būtu atspoguḷotas arī vārdu valentās pazīmes, no otras puses, to balsta automātiskas valodas analīzes un informācijas ieguves programmrīku izstrāde.

Īpašas uzmanības vērti ir pētījumi, kuros verba valence ir analizēta tekstā. Šajā gadījumā verbu valences īpatnības tiek konstatētas nevis intuitīvi un vispārināšanas rezultātā, bet gan balstoties uz konkrētiem lietojuma piemēriem, kuros skaidri parādās vārda valenci noteicošie faktori.

Ekscerpētās krievu-latviešu paralēles rāda, ka parasti aplūkotajos tekstos (A. Čehova stāstos un to latviskajos tulkojumos) runas verbu raksturo viens adverbs, sporādiski ir sastopams runas verbu saistījums ar vairākiem adverbiem. Veiktā analīze atklāj, ka kvantitatīvi pārstāvētāks ir runas verbu saistījums ar adverbu skaļi, kas nepārprotami izcel̦ skaļumu kā pragmatiski būtisku runas pazīmi. Semantikas ziṇā adverbi galvenokārt raksturo vispārinātas nozīmes runas verbus, tādējādi piešķirot verbam ne tikai jēdzienisko konkrētību, bet arī emocionāli ekspresīvās un vērtējošās konotācijas.

Atslēgvārdi: runas verbs, adverbs, saistījums, semantika, adverbiālā sēma, pazīme.

Jau 20. gs. 80. gados latviešu valodniecībā pievērsties runas verbu semantisko īpatnību un saistāmības jautājumu vispusīgai izpētei rosinājusi Inta Freimane. Valodnieces pētījumiem bijusi gan teorētiska, gan praktiska nozīme, jo tajos sniegts arī skaṇu verbu (runas verbi plašākā izpratnē ir uzskatāmi par skaṇu 
verbiem) distributīvs leksikogrāfisks modelis, pēc kura varētu veidot šīs leksikas grupas tematisku vārdnīcu. Pēc I. Freimanes (1984, 2-4) domām, šāda vārdnīca l̦autu gan aprakstīt verbus vienotā leksikogrāfiskā sistēmā, skaidrot un ilustrēt to nozīmi, gan raksturot galvenos skaņu verbu saistījuma tipus tematiskā skatījumā.

Līdzīgu viedokli paudusi Gal̦ina Zolotova (Galina Zolotova). Viņa akcentējusi, ka nepieciešams izstrādāt jauna tipa vārdnīcas, kur būtu realizēta leksikas un gramatikas mijiedarbības ideja. G. Zolotova $(1988,4)$ raksta: „Mūsdienās sintaksi vairs neaplūko atrauti no semantikas - sintaktisko konstrukciju izveide ir atkarīga no tās komponentu leksiski gramatiskajām īpatnībām. Šis apgalvojums vairs neprasa pierādījumu - tas gaida šì materiāla sistematizāciju."

Verba nozīmīgā un organizējošā loma teikuma semantiskajā struktūrā un valodas sistēmā kopumā nav apšaubāma. Vladimirs Vinogradovs (Vladimir Vinogradov 1986, 351-356) vienmēr ir uzsvēris verba semantiskās struktūras ietilpību, plašumu un elastību, norādot, ka verba semantiskais plašums nosaka arī verba sintaktiskās potences. I. Freimane $(1975,3)$ savukārt atzinusi, ka bez verbu valences izpētes nav iespējams risināt teikuma struktūras jautājumus sintaksē. Svarīgi ir verba valences leksiskie un semantiskie faktori, jo verba nozīmes jēdziens nav atdalāms no verba spējas saistīties ar citiem vārdiem.

Mūsdienu lingvistikā interese par verba valences jautājumiem ir saistīta ar vairākiem iemesliem. Pirmkārt, ar leksikalizētās gramatikas izveidi, otrkārt, ar komplekso vārdnīcu izstrādi, kurās būtu atspoguḷotas arī vārdu valentās pazīmes (Murāne et al. 2002, 51), treškārt, ar automātiskas valodas analīzes un informācijas ieguves programmrīku izmantošanu (Nešpore 2012, 195).

Lingvistiskajā literatūrā ir atzīmēts, ka vārdiem ar līdzīgu nozīmi piemīt gan kopīgas semantiskās pazīmes, gan tipisks saistījums un funkcionēšana. Kā rakstījusi I. Freimane $(1975,14)$, šāda analīze (verbu analīze tekstā, ar citātu piemēriem) ir vēlama, it īpaši leksiski semantiskās grupas ietvaros. Šajā gadījumā verbu valences īpatnības tiek konstatētas nevis intuitīvi un vispārināšanas rezultātā, bet gan balstoties uz konkrētiem lietojuma piemēriem, kuros skaidri parādās vārda valenci noteicošie faktori.

Minētie atzinumi arī motivējuši pievērsties krievu un latviešu valodas runas verbu saistāmības īpatnību analīzei. Pētījuma empīrisko bāzi veido vairāk nekā 100 runas verbu lietojuma piemēru, kas ekscerpēti no Antona Čehova stāstiem un to tulkojumiem latviešu valodā. Uzmanība pievērsta tam, kādi lingvistiskie un ekstralingvistiskie faktori nosaka runas verbu saistījumu ar adverbiālas nozīmes paplašinātājiem, kas formāli izteikti ar apstākl̦a vārdiem.

Saskaņā ar I. Freimanes viedokli semantiskajā saistāmībā runas verbiem, tāpat kā visiem latviešu valodas verbiem kopumā, galvenais saistījums ir ar subjektu un ar objektu resp. subjekta orientācija, kā arī objekta orientācija, adverbiāla saistāmība trīspersonu verbiem nav tik raksturīga. Tomēr jāšķir vārda potenciālā spēja no šīs spējas konkrētās realizācijas tekstā, verbam stājoties noteiktās kombinācijās ar citiem vārdiem (Freimane 1975, 11-12, 38; Freimane 1976, 88-90).

Viens no avotiem, kur tiek atspogulıots vārda saistījums ar citiem vārdiem, ir skaidrojošās u. c. vārdnīcas, kur bieži vien vārda nozīmes definīciju papildina ilustratīvais materiāls. No vienas puses, tā uzdevums ir atklāt vārda lietojumu kontekstā, no otras puses, papildināt skaidrojumu ar sīkākām nozīmes niansēm. 
Tā „Latviešu literārās valodas vārdnīcā” (www.tezaurs.lv/llvv) atrodami šādi runas verbu adverbiālie raksturojumi: jautri runāt; dedz̄̄gi runāt; runāt mierīgi; prot izteiksmīgi runāt dzejoḷus; atbildēja nedroši u. c. Savukārt „Krievu valodas vārdu saistāmības vārdnīcā" (Denisov et al. 1983) verba говорить (runāt) saistāmību ar adverbiem ilustrē 26 vārdi: быстро, вежливо, громко, грубо, великолепно, интересно, любезно, медленно, наедине, открыто, откровенно, охотно, (не)плохо, прекрасно, прилично, просто, прямо, решительно, свободно, серьезно, спокойно, скоро, тихо, хорошо, четко (Denisov et al. 1983, 104), runas verbu ответить/отвечать (atbildēt) 13 apstākl̦a vārdi: быстро, весело, громко, немедленно, отрицательно, положительно, радостно, решительно, сразу, срочно, тихо, уверенно, шепотом (Denisov et al. 1983, 354-355), bet runas verbu спросить/спрашивать (jautāt) 9 adverbi: быстро, вежливо, громко, грубо, ласково, откровенно, прямо, серьезно, строго, тихо (Denisov et al. 1983, 549). Protams, vārdnīcu ilustratīvais materiāls rāda vārda funkcionēšanas iespējas un uzskatāmākos piemērus, taču objektīvu iemeslu dēḷ leksikogrāfiskie avoti nespēj pilnībā atspoguḷot vārda potenciālo valenci, kas varētu piemist noteiktas semantikas vārdiem.

Te jāpiebilst, ka informācija par darbības norisi var būt realizēta arī ar adverbiālās sēmas implikāciju attiecīgā verba semantiskajā struktūrā. Latviešu un krievu valodas skaidrojošo vārdnīcu dotumi atklāj, ka adverbiālus raksturojumus īsteno virkne implicēto sēmu. Ilustrācijai var minēt dažus piemērus, sal.: čukstēt 'runāt bez balss saišu vibrācijas; runāt ļoti klusu'; bubināt 'klusi, neskaidri teikt, sacīt'; bērt 'runāt (ātri, nepārtraukti)'; opamb (bḷaut) 'runāt l̦oti skaļi'; mpemamb (tarkšksēt) 'runāt ātri un daudz'; мямлить (murkšksēt) 'lēni, neskaidri un negribīgi runāt'. „Krievu valodas verbu ideogrāfiskās vārdnīcas” materiāls apliecina, ka adverbiālās sēmas parasti ir implicētas t. s. specifisku runas verbu semantiskajā struktūrā, piem., брюзжать (kurnēt), бубнить (bubināt), лопотать (buldurēt), лепетать (lalināt), шамкать (čāpstināt) u. c. (Babenko 1999, 349-379).

Tomēr piln̄̄gāk runas verbu saistījums ar adverbiem izpaužas reālā lietojumā. Staņislavs Siḷinskis (Silinskij 1995, 3) raksta: „Faktoloǵiskā materiāla ekscerpēšana no tekstiem, nevis no vārdnīcām l̦auj ne tikai gūt vārda lietojuma piemērus, bet arī netieši konstatēt visbiežāk lietotos noteiktas grupas vārdus, atklāt vārda nozīmēs apslēptu, taču komunikatīvi iederīgu jēgu." Tādējādi, kā jau tika minēts, pētījuma empīriskā bāze balstās uz krievu un latviešu valodas runas verba un adverba saistījumu piemēriem, kas ekscerpēti no oriǵinālteksta un tulkojuma.

Ekscerpētās krievu-latviešu paralēles l̦auj secināt, ka aplūkotajos tekstos runas verbu saistījums ar vairākiem adverbiem sastopams visai reti - konstatēts tikai viens piemērs, kur runas verbam ir saistījums ar trīs adverbiem, sal.:

(1) Зато мой Петр Петрович, у которого еще со студенчества осталась манера всякий разговор сводить на спор, говорил скучно, вяло и длинно, с явным желанием казаться умным и передовым человеком. (Дом с мезонином); Turpretim mans Pjotrs Petrovičs, kuram vēl no studenta laikiem bija palikusi paraža katru sarunu novadīt uz strīdu, runāja garlaicīgi, gausi un gari, acīmredzot vēlēdamies izlikties gudrs un progresīvs. (Māja ar mezonīnu, tulk. A. Kurcijs, 275) 
No oriǵinālteksta un tulkojuma fragmentiem redzams, ka apstākḷa vārdi ir piesaistīti verbiem говорить un runāt, kuri kontekstā realizē tikai vispārinātu runāšanas semantiku 'mutiski paust domas, viedokli', tādējādi vairāku adverbu lietojums kontekstā l̦auj konkretizēt darbību, kvalificējot to gan no ilguma un saturīguma, gan no vērtējošo konotāciju viedokḷa. Adverbu uzskaitîjumam ir arī īpaša stilistiska slodze: no vienas puses, tas l̦auj radīt jēdzieniskās gradācijas iespaidu, no otras puses, aktualizēt potenciālās adverbiālās sēmas 'neestētiski', 'bezgaumīgi', 'bezjēê̄ịi', 'pārspīlēti' un piešķirt personāža portretējumam spilgtas emocionāli ekspresīvas nokrāsas.

Sporādiski ir sastopams arī runas verba saistījums ar diviem adverbiem. Semantikas zin̄ā šāds runas verbu un adverbu saistījums izpaužas divējādi. Pirmkārt, adverbi niansēti ataino kādu vienu verbā ietvertās nozīmes aspektu, kad kontekstā nepieciešams izteikt noteiktas pazīmes pastiprinājumu vai precizējumu, sal.:

(2) И всё она выражалась так степенно, так рассудительно, подражая мужу ... (Душечка); Un vienmēr Oḷa runāja tik cien̄̄gi, tik prātīgi, atdarinādama vīru .. (Sirsniņa, tulk. J. Ozols, 382)

(3) Не глядя на нас, она очень серьезно и обстоятельно рассказала нам, сколько сгорело домов в селе Сиянове, сколько мужчин, женщин и детей осталось без крова ... (Дом с мезонином); Uz mums neskatīdamās, vinga ļoti nopietni un pamatīgi mums izklāstīja, cik māju nodedzis Sijanovas ciemā, cik vīriešu, sieviešu un bèrnu palicis bez pajumtes .. (Māja ar mezonīnu, tulk.

A. Kurcijs, 273)

Kā zināms, runas verbu leksiski semantiskās grupas robežas ir labilas, jo verbi semantiskās difūzijas dēḷ līdz ar nozīmi 'runāt' var eksplicēt vēl kādu ar runāšanu kopsakarībā esošu procesu un darbību, un šajā gadījumā piesaistītie adverbi степенно - cien̄igi, рассудительно - prātīgi, серьезно - nоріеті, обстоятельно - pamatīgi u.c. nepārprotami norāda intelektuālās darbības klātesmi. Šksiet, ka tieši adverbu nopietni un pamatīgi iespaidā, kuri atklāj darbības intelektuālus raksturojumus, A. Kurcijs krievu valodas verbu рассказать (stāstīt) tulko ar semantiski diferencētāku runas verbu izklāstīt, kura nozīmes struktūrā ir implicēta sēma 'skaidrojot' ('padarīt pilnīgi saprotamu').

Otrkārt, krievu-latviešu paralēles liecina, ka piesaistītie adverbi kontekstā eksplicē atšksirīgus darbības raksturojumus. Vispirmām kārtām ekscerpētie piemēri l̦auj secināt, ka viena no darbības pazīmēm, kas bieži tiek verbalizēta kontekstā, ir runas skaļums. Šìs dominējošās pazīmes aktualizācija lielā mērā ir skaidrojama ar to, ka skaļums ir gan objektīvi pastāvoša, gan komunikatīvi būtiska runas pazīme, kuru autors uztver kā pragmatiski nepieciešamu. Balss skaļuma palielināšanās signalizē par izteikuma voluntatīvām un emocionālām konotācijām, jēdzieniski nozīmīgākajām dal̦ām. Te vietā minēt Jurija Uljjanova (Jurij Ul’janov 1988, 19) asociatīvo pētījumu, kura mērķis bija eksperimentāli noskaidrot, ar ko asociējas noteikti stimulvārdi, tostarp arī daži runas verbi. Asociatīvā eksperimenta rezultātā tika konstatēts, ka noteikti stimulvārdi izraisa noteikta tipa reakcijas un ka visspilgtāk stereotipu veidi izpaužas paradigmatiskās un sintagmatiskās asociācijās. Pēc J. Uljanova $(1988,92 ; 136)$ vārdnīcas materiāla var spriest, ka pirmā verbālā 
reakcija uz stimulvārdu kliegt un runāt ir bijusi tieši skaļi (pārējās reakcijas ir spalgi, klusi, daudz, àtri, ilgi, gari, skaidri, mierīgi, skaisti).

Darbības pazīmes akcentēšanai vai precizēšanai līdz ar skaļumu kontekstā var būt verbalizēta vēl kāda darbības pazīme. Piem., otrs adverbs var norādīt darbības kvantitātes un intensitātes pastiprinājumu, sal.:

(4) Это была живая, искренняя, убежденная девушка, и слушать ее было интересно, хотя говорила она много и громко - быть может оттого, что привыкла говорить в школе. (Дом с мезонином); Tā bija mundra, sirsnīga, pārliecības pilna jaunava, un klausīties viņā bija interesanti, kaut gan vinga runāja daudz un skal̦ - varbūt tāpēc, ka bija ieradusi runāt skolā. (Māja ar mezonīnu, tulk. A. Kurcijs, 275)

(5) Он гнусавил от непривычки говорить много и быстро, заикался и, чувствуя такой недостаток своей речи, старался скрасить его жестикуляциией головы, рук и тощчих плеч ... (Счастье); Neradis runāt daudz un ätri, viņš murkšksēja caur degunu, stostījās un, apzinādamies šo savas runas trūkumu, pūlējās to padarìt mazāk manāmu, mētādamies rokām, visādi grozīdams galvu un vājos plecus .. (Laime, tulk. A. Rudzroga, 108)

Retāk runa no skaļuma viedokḷa var būt raksturota arī diametrāli pretēji kā klusa, vāji dzirdama, neintensīva. Oriǵināltekstā šo semantiku aktualizē adverbi тихо, шёпотом, вполголоса, savukārt tulkojumā to latviskie ekvivalenti klusi, klusītēm, čukstus, sal.:

(6) Он смотрел ей в неподвижные, испуганные глаза, иеловал ее, говорил тихо и ласково ... (Дама с собачкой); Gurovs raudzījās vingas stingrajās, bailspilnajās acīs, skūpstīja viņu, runāja klusi un maigi .. (Dāma ar sunīti, tulk. R. Ezera, 393)

(7) - Как жаль, - говорит он медленно и тихо, покачивая головой и не глядя в глаза собеседнику ... (Палата № 6); - Cik žēl, - vinšs runā gausi un klusītēm, šüpodams galvu un neraudzīdamies sarunas biedram acīs .. (Sestā palāta, tulk. A. Rudzroga, 195)

(8) - Вы же никому не рассказывайте, барин... - прибавила она вдруг шёпотом. (Агафья); - Jūs taču nevienam nestāstīsiet, kungs... - viņa piepeši čukstus piebilda. (Agafja, tulk. R. Ezera, 71)

(9) Потом она вполголоса, нараспев, рассказывала про Москву, про свою жизнь ... (Мужики); Pēc tam Olga sāka paklus̄̄a, dziedošā balsī stāstīt par Maskavu, par savu dzīvi .. (Zemnieki, tulk. P. Kalva, 292)

Adverbi тихо - klusi, шёпотом - čukstus, вполголоса - pusbalsī u. tml. vienlaikus ar denotatīvās sēmas 'klusi' realizāciju kontekstā balsta arī dažādu asociatīvi pragmatisko sēmu 'slepeni', 'konfidenciāli', 'intīmi', 'bailīgi', 'kautrīgi' aktualizāciju. Valentīna Čerņaka (Valentina Chernjak 2000, 177-178) runas verbus semantikas ziṇā definē kā konkrētus, t.i., tieši novērojamus. Tādējādi vairāku adverbu lietojums l̦auj kvalificēt darbību ar savstarpēji saistītām semantiskām niansēm un veidot vēstījuma asociatīvi tēlaino fonu, paspilgtinot to ar akustiskiem un emocionāliem iespaidiem. 
Tomēr oriǵinālteksta un tulkojuma kontekstuālā analīze rāda, ka parasti runas verbs piesaista vienu apstākḷa vārdu. Aplūkojot šādus piemērus, jāizceḷ tādi runas verba un adverba saistījumi, kurus raksturo ciešs semantisks saskaņojums, proti, kad verba un adverba nozīmes struktūru veido vairākas kopīgas sēmas. Šajā gadījumā runas verba un piesaistîtā adverba lietojuma dēl kontekstā vienlaikus tiek aktualizēta gan eksplicīta, gan implicīta informācija. Tā krievu valodas runas verba сознаваться un latviešu valodas atzīties nozīmes struktūrā ir implicēta adverbiālā sēma 'atklāti' ('izpaust'), kuru kontekstā formāli aktualizē vēl adverbi откровенно un valssirdīgi - 'parasti pilnībā atklājot savas domas, pārdzīvojumus; atklāti', sal.:

(10) ... затем виолончелист, у которого инструмент плакал и который откровенно сознавался, что из всех знакомых ему женщин умеет аккомпанировать одна только Ольга Ивановна ... (Попрыгунья); .. tad čellists, kura instruments raudāja un kurš valsirdīgi atzinās, ka no visām viņam pazīstamajām sievietēm pavadìt uz klavierèm protot vienīgi Olga Ivanovna .. (Vējagrābsle, tulk. V. Grēviņš, 157)

Arī nozīmi 'dusmīgi' kontekstā verbalizē gan attiecīgie adverbi cepdumo un dusmīgi, gan krievu valodas zoomorfiskais verbs uunemb un tā latviskais ekvivalents šņākt, ja tos lieto antropomorfiskā funkcijā runas darbības nominācijai 'ar dusmām, apslāpētā balsi runāt', sal.:

(11) ... он страшно конфузился и, когда уходили гости, хватал ее за руку и шипел сердито: - Я ведь просил тебя не говорить о том, чего ты не понимаешь! (Душечка); .. bet veterinārārsts briesmīgi mulsa un, kad ciemiņi aizgāja, satvēra Oḷas roku un dusmīgi šņāca: - Es taču tevi esmu lūdzis nerunāt par to, ko tu nesaproti! (Sirsniņa, tulk. J. Ozols, 383)

Formāli izteiktas un neizteiktas informācijas korelāciju ilustrē arī citi runas verbu un adverbu saistījuma gadījumi, piem., adverbiālo sēmu 'skaḷi' runas verbi крикнуть un iekliegties realizē implicīti, savukārt verbiem piesaistītie apstākḷa vārdi громко un skaļi - eksplicīti, sal.:

(12) Ольге Ивановне хотелось громко крикнуть, ударить художника по голове чем-нибудь тяжельмм и уйти ... (Попрыгунья); Olgai Ivanovnai gribējās skaḷi iekliegties, iesist ar kaut ko smagu gleznotājam pa galvu un aiziet .. (Vējagrābsle, tulk. V. Grēviņš, 174)

Adverbiālo nozīmi 'pēkšņi' un 'īslaicīgi' oriǵināltekstā aktualizē arī runas verbi вскрикнуть, крикнуть, гаркнуть, bet latviskajā tulkojumā - to ekvivalenti iekliegties, iebrēkties, ierēkties. Adverbiālās sēmas runas verbiem piešksir derivatīvie afiksi: priedēklis $6 c$ - un ie-, piedēklis $-\mu y$-, latviešu valodā - galotne -ties. Lai gan adverbiālā semantika 'pēkšņi' un 'îslaicīgi' jau ir ietverta runas verba nozīmē, A. Čehovs lietojis arī apstākḷa vārdu вдpyz, kurš kontekstā aktualizē vairākas asociatīvās sēmas 'nejauši', 'neapzināti', 'netīšām', 'negaidīti', sal.:

(13) - Это чёрт знает что такое! - вскрикнул воруг Иван Дмитрич и вскочил. (Палата № 6); - Lai velns parauj! - Ivans Dmitričs pēkšņi iekliedzās, pielēkdams kājās. (Sestā palāta, tulk. A. Rudzroga, 228) 
(14) - Любавкин! - вдруг крикнул он так громко, что все почтальоны и посетители вздрогнули. (Палата № 6); - Lubavkin! - viņš piepeši iebrēcās tik skaļi, ka visi pastnieki un apmeklētāji sarāvās. (Sestā palāta, tulk. A. Rudzroga, 223)

(15) - Пошел вон!! - гаркнул вдруг посиневший и затрясшийся генерал. (Смерть чиновника); - $\bar{A} r \bar{a} ! !$ - pēkšnni ierēcās generālis, kļūdams zils aiz dusmām un sākdams trīcēt. (Ierēdṇa nāve, tulk. V. Grēviņš, 19)

Nenoliedzami, šādam semantiskam paspilgtinājumam, ko veido eksplicītas un implicītas informācijas korelācija, kontekstā ir estētiska nozīmība - padarīt vēstījumu dinamiskāku, spraigāku un emocionāli ekspresīvāku.

Tomēr pēc analizējamā materiāla redzams, ka vairākumā gadījumu starp runas verbu un piesaistīto adverbu vērojamas semantiskas atškirīības. Kontekstuālā analīze atklāj, ka runas darbības lokālie raksturojumi A. Čehova stāstos ir verbalizēti visai reti - šāds runas verbu un adverbu saistījums ir sporādisks, sal.:

(16) Он намекал на Владимира IV степени и уже воображал, как он будет всюду рассказывать об этом своем каламбуре, удачном по находчивости и смелости ... (Анна на шее); Ar to bija dots mājiens uz IV pakāpes Vladimiru, un viņš jau iztēlojās, kā visur stāstīs par šo savu asprātīgo un drošsirdīgo kalambūru .. (Anna kaklā, tulk. R. Ezera, 271)

Kvantitatīvi pārstāvētāka ir ekscerptu grupa, kas ilustrē runas verbu saistījumu ar laika adverbiem. Lai gan aplūkotajos piemēros konstatēti vairāki laika adverbi, kas izsaka dažādus laika jēdzienus (konkrētu un nekonkrētu darbības norises laiku, ilgstošu un nepārtrauktu vai īslaicīgu un epizodisku darbību), tomēr kopumā arī temporālie raksturojumi izvēlētajos tekstos runas darbību kvalificē samērā reti, sal.:

(17) - Вчера мы беседовали так мирно, но вдруг вы почему-то обиделись и сразу оборвали ... (Палата № 6); - Vakar mēs tik mierīgi sarunājāmies, te uzreiz jūs diez kāpēc apvainojāties un spēji pārtraucāt .. (Sestā palāta, tulk. A. Rudzroga, 205)

(18) Ольга Ивановна всегда звала мужа, как всех знакомых мужчин, не по имени, а по фамилии ... (Попрыгунья); Olga Ivanovna arvien sauca vīru, tāpat kā visus pazīstamos vīriešus, nevis vārdā, bet uzvārdā .. (Vējagrābsle, tulk. V. Grēviņš, 175)

(19) В городе холостяки нарочно ходят в баню и в рестораны, чтобы только поговорить, и иногда рассказывают банщикам или офиџиантам очень интересныле истории ... (О любви); Pilsētās vecpuiši tieši tāpēc apmeklē pirtis un restorānus, lai dabūtu parunāties, un dažkārt izstāsta pirtniekam vai viesmīlim visai interesantus notikumus .. (Par mīlestību, tulk. P. Kalva, 359)

(20) Если, идя с ней в театр, я забывал взять бинокль, то потом она говорила: - Я так и знала, что вы забудете. (О любви); Ja, ejot kopā ar viņu uz teātri, es biju aizmirsis paņemt lìdzi binokli, tad viña vēeläk man teica: - Es jau skaidri zināju, ka jūs aizmirsīsit. (Par mīlestību, tulk. P. Kalva, 365) 
(21) - Мы не имеем тайн друг от друга, я должна сейчас рассказать всё маме и сестре ... (Дом с мезонином); - Mums nav noslēpumu, man tülīt viss jāizstāsta mātei un māsai .. (Māja ar mezonīnu, tulk. A. Kurcijs, 286)

Jāpiebilst, ka runas verbu nozīmes struktūrā adverbiālās sēmas ar temporālu vai lokālu nozīmi nav raksturīga parādība. Lokāla un temporāla informācija vairāk ir svarīga plašākam situācijas raksturojumam, tāpēc parasti vietas un laika adverbi raksturo nevis runas darbību, bet visu teikumu kopumā.

Tāpat izraudzītajos tekstos epizodiski sastopams runas verbu saistījums ar mēra adverbiem, sal.:

(22) ... мь же, наше поколение, дурно спим, томимся, много говорим и всё решаем, правы мы или нет. (Случай из практики); .. taču те̄s, mūsu paaudze, slikti gul̦am, tvīkstam gaidās, daudz runājam un visu laiku spriežam - vai mums ir taisnība vai nav. (Gadījums praksē, tulk. J. Ozols, 375)

(23) Про Волчаниновых сообщзл он немного. (Дом с мезонином); Par Volčaņinovām viņš pastāstīja nedaudz. (Māja ar mezonīnu, tulk. A. Kurcijs, 287)

(24) Она говорила вообще очень мало, всегда молчала и всё думала, думала ... (Анюта); Viņa vispār runāja lıoti maz, vairāk klusēja un tikai domāja, domāja .. (Aņuta, tulk. R. Ezera, 59)

(25) ... [Пустовалов] сидел недолго, минут десять, и говорил мало ... (Душечка); .. [Pustovalovs] pasēdēja ìsu laiciņu, minūtes desmit, runāja maz.. (Sirsniņa, tulk. J. Ozols, 380)

Parasti mēra adverbi, niansēti norādot uz darbības pazīmes kvantitāti vai intensitāti, noder vēstījuma emocionāli ekspresīvā fona pastiprinājuma vai pavājinājuma nokrāsu radīšanai.

Ekscerpēto piemēru vairākums atklāj, ka galvenokārt runas verbi piesaista veida adverbus. Vispārinot veida adverbu nozīmes, var konstatēt, ka liela daļa krievu un latviešu valodas apstākḷa vārdu kontekstā norāda runas intonācijas īpatnības. Runas intonācija izteikumam, teikumam vai tekstam piešķir dažādas emocionālas nokrāsas, kā arī atvieglo teksta uztveri, jo izceḷ būtisko, parāda runātāja attieksmi pret teksta saturu (Auziņa 2013, 107). Piem., adverbi глубокомысленно - dzilldomīgi, бессвязно - nеsakarīgi, значительно - zìmīgi, машинально - automātiski, neapzināti u.c. norāda runas darbības intelektuālu pazīmi, sal.:

(26) Тот, всё ещуе багровый от стыла и гнева, бессвязно произнес какуюто ненужную клятву, надел фуражку и вышел. (Палата № 6); Tas, vēl joprojām kaunā un dusmās piesarcis, nesakarīgi izgrūda kādu nevajadzīgu zvērestu, uzmauca galvā cepuri un aizgāja. (Sestā palāta, tulk. A. Rudzroga, 218)

(27) Андрей Ефимыч сидит, подперев щеку кулаком, задумавшись, и машинально задает вопросы. (Палата № 6); Andrejs Jefimičs sēž, vaigu pret dūri atbalstījis un aizdomājies, un automātiski uzdod jautājumus. (Sestā palāta, tulk. A. Rudzroga, 193) 
Tomēr vēstījuma jēdzieniskās koncentrētības labad autors runas verbiem piesaistīijis apstākl̦a vārdus, kuri atkarībā no konteksta spēj izteikt l̦oti atšksirīgas subjektīvi emocionālās un psihiskās nokrāsas. Krievu un latviešu valodas adverbi весело - līksmi; встревоженно - nетіerīgi, satraukti; грубо - asi, rupji; грустно - skuтji; ласково - maigi, laipni, mīlīgi; назойливо - иzplijīgi; нервно nеrvozi; печально - skumīgi, skuтji; робко - bikli; сердито - dusmīgi, nikni; слезливо - pusraudus; угрюмо - drūmi, ìgni; уныло - bēdīgi; хладнокровно vienaldzīgi, aukstasinīgi; холодно - salti, vēsi u.c. var atspoguḷot gan runātāja reakciju uz situāciju, gan klausītāja attieksmi pret runātāju un izteikumu, sal.:

(28) - Я в этом ничего не понимаю, - угрюмо заявляет Иван Дмитрич. (Палата № 6); - Es nekā tur nesaprotu, - Ivans Dmitričs drūmi nosaka. (Sestā palāta, tulk. A. Rudzroga, 188)

(29) - Я принесла вам этюд ... - сказала она робко, тонким голоском, и губь ее задрожали, - nature morte. (Попрыгунья); - Es jums atnesu studiju .. viņa teica bikli, smalkā balstiņā, un vingai ietrīcējās lüpas, - nature morte. (Vējagrābsle, tulk. V. Grēviņš, 174)

(30) Я знал о слабости прекрасного пола к Савке и знал, как он неохотно говорил о ней, а потому не продолжал своего допроса. (Агафья); Es zināju, ka skaistajam dzimumam ir vājōba pret Savku, un zināju arī, cik nelabprāt viņš runā par to, tāpēc neko sīkāk neizprašņāju. (Agafja, tulk. R. Ezera, 70)

Piesaistītais adverbs var norādīt arī runas pārtraukumus, kas parasti ir saistīti ar runātāja emocionālo stāvokli un vēlmi piešķirt vārdam vai izteikumam īpašu noz̄imi. Kontekstā šādu informāciju var realizēt, piem., adverbi невnоnad izklaidīgi, торопливо - steidzīgi, sal.:

(31) Наденька нетерпеливо, грустно, проникающим взором заглядывает мне в лиць, отвечает невпопад, ждет, не заговорю ли я. (Шуточка); Nadjeņka te nepacietīgi, te skumīgi, te pētījoši palūkojas manī, atbild izklaidīgi, gaida, vai neierunāšos. (Jociņš, tulk. R. Ezera, 63)

(32) - Ничего, все обошлось благополучно, - рассказывала Надя торопливо. (Невеста); - Nekas, viss beidzās labi, - Nadja steidzīgi stāstīja. (Līgava, tulk. A. Grēviņa, 417)

Adverbi, kas norāda runas intonatīvus raksturojumus, daiḷdarbā realizē plašas mākslinieciskās funkcijas: rada runas situācijas noskaņas, personāža runas portretējuma individualizāciju un tipizāciju, paspilgtina vēstījuma ekspresivitāti, akcentē svarīgu informāciju.

Oriǵinālteksta un tulkojuma sastatīšanas gaitā tiek konstatēts gan samērā augsts stabilo ekvivalentu īpatsvars, gan arī daudz netipisku, individuālu atbilsmju, kas vērojamas tikai kādā atsevišksā kontekstā. Tā atšķirīgu informāciju oriǵināltekstā un V. Grēviņa tulkojumā eksplicē krievu valodas adverbs томно ar nozīmi 'emocionāls stāvoklis, kam raksturīgas neskaidras, nepamatotas skumjas, nogurdināti maigs' un latviešu valodas adverbs tīksmi ar nozīmi 'emocionāls stāvoklis (cilvēkam), kam raksturīgas l̦oti patīkamas izjūtas, dziļšs apmierinājums’, sal.: 
(33) И вспоминала она также, что в последний раз он приходил к ней в каком-то сером сюртучке с искрами и в новом галстуке и спрашивал томно: „Я красив?” (Попрыгунья); Un turklāt viņa atcerējās, ka beidzamo reizi Rjabovskis bija atnācis pie vinas pelēkos, lāsmainos svārciños ar jaunu kaklasaiti un tīksmi vaicājis: „Vai esmu skaists?” (Vējagrābsle, tulk. V. Grēviņš, 171)

Domājams, ka minētajā kontekstā V. Grēviņš varētu lietot kādu precīzāku latviešu valodas ekvivalentu, piem., adverbu gurdeni, kas tulkojumā aktualizētu atbilstošas gan jēdzieniskās, gan emocionāli vērtējošās nokrāsas. Turklāt jāpiebilst, ka tulkotājs V. Grēviņš līdzịā kontekstā krievu valodas adverbu томно atveido ar precīzāku ekvivalentu smagi ar nozīmi 'tāds, kam ir drūms, nospiests garastāvoklis (par cilvēku)', sal.:

(34) - Я устал... - томно проговорил художник, глядя на этюд и встряхивая головой, чтобь побороть дремоту. (Попрыгунья); - Esmu noguris... mākslinieks smagi noteica, raudzīdamies studijā un pakratīdams galvu, lai pārvarētu snaudu. (Vējagrābsle, tulk. V. Grēviņš, 174)

Krievu un latviešu valodas adverbu sastatāmās analīzes gaitā atklātas arī citas tulkošanas transformācijas, piem., papildinājums un izlaidums, kas liecina, ka konteksts vai citi faktori tulkojumā var motivēt gan adverbiālo pazīmju aktualizāciju, gan nivelēšanu, sal.:

(35) - А я тебе говорю, что я читал! - кричит еще громче Коваленко. (Человек в футляре); - Bet es tev saku, ka lasīju! - Kovaļenko tagad kliedz vēl skal̦āk. (Cilvēks futrālī, tulk. P. Kalva, 341)

(36) Опять все три голоса запели вместе. (Бабы); Visas trīs balsis atkal sāka dziedāt. (Sievišksi, tulk. J. Ozols, 149)

Veiktā analīze l̦auj formulēt dažus vispārinājumus:

Oriǵināla un tulkojuma kontekstuālā analīze rāda, ka galvenokārt apstākḷa vārdi raksturo vispārinātas nozīmes runas verbus (piem., runāt, sacīt, teikt, parunāt u.c.), kuru nozīmes struktūrā nav diferencējošo sēmu un kas no emocionāli stilistiskā viedokḷa ir neitrāli. Piesaistītie adverbi detalizē vispārinātas nozīmes runas verbos gan jēdzieniskā, gan konotatīvā aspektā.

Piesaistīto apstākḷa vārdu semantika atklāj, ka runas darbība vispirmām kārtām tiek diferencēta no intonatīvo pazīmju viedokḷa. Kontekstā adverbiālās pazīmes, ko verbalizē veida apstākḷa vārdi, darbībai piešķir jēdzienisku konkrētību un emocionāli vērtējošas nokrāsas. Šai zin̄ā īpašā stilistiskā slodze piemīt sinkrētiskiem adverbiem, kuru nozīme var modificēties atkarībā no konteksta, paspilgtinot vēstījumu ar atšķirīgām semantiskām niansēm un paplašinot teksta interpretācijas iespējas.

Analizētajos tekstos kvantitātes ziņā mazāk pārstāvēts ir runas verbu saistījums ar vietas, laika un mēra adverbiem. No komunikatīvi pragmatiskā viedokḷa runas darbības lokālie, temporālie un kvantitatīvie raksturojumi salīdzinājumā ar intonatīvajiem vērtējami kā sekundāri. Semantikas un neitrālās konotācijas dēl 
šo adverbu mākslinieciskās funkcijas nav tik plašas, it īpaši dažādu subjektīvi vērtējošo nokrāsu aktualizācijas zin̄ā.

Viena no dominējošajām adverbiālajām pazīmēm, kas tiek aktualizēta izvēlētajos tekstos, ir runas skaļums. Tas nozīmēe, ka autors šo pazīmi uztver kā pragmatiski būtisku, piem., no komunikatīvo mērķu sasniegšanas viedokḷa. Ekscerpētajā materiālā šì pazīme tiek verbalizēta visbiežāk.

Parasti starp runas verbu un piesaistīto adverbu konstatētas iekḷaušanas attieksmes, proti, pēc sēmu sastāva apstākḷa vārda nozīme ir plašāka nekā runas verba, kā arī konstatētas šksēluma attieksmes, kad katrā no vārdu nozīmēm ir atšķirīgas sēmas. Reizēm starp runas verbu un piesaistīto adverbu vērojamas implikatīvas attieksmes, kad abu vārdu nozīmju komponenti sakrīt. Ciešs semantisks saistījums paspilgtina kontekstu ar noteiktām adverbiālām pazīmēm un ekspresīvām konotācijām.

Runas verbu un adverbu saistījumu piemēri spilgti ilustrē gan eksplicītas un implicītas informācijas korelāciju, gan valodas līdzekḷu sinonīmiju.

\section{Literatūra}

1. Auziņa, Ilze. 2013. Runas intonācija un tās elementi. Latviešu valodas gramatika. Nìtina, Daina, Grigorjevs, Juris (red.). Rīga: LU Latviešu valodas institūts, 107120.

2. Babenko, Ljudmila. 1999. Tolkovyj slovar' russkih glagolov: Ideograficheskoe opisanie. Anglijskie jekvivalenty. Sinonimy. Antonimy. Moskva: AST-Press.

3. Chernjak, Valentina. 2000. Semantika chastej rechi i resursy russkoj sinonimiki. Jazyk. Funkcii. Zhizn': Sbornik statej v chest' professora A. V. Bondarko. SanktPeterburg.

4. Čehovs, Antons. 1985. Stāsti. Rīga: Liesma.

5. Denisov, Petr et al. 1983. Slovar' sochetaemosti slov russkogo jazyka. Moskva: Russkij jazyk.

6. Freimane, Inta. 1975. Verbu tematiskā klasifikācija un saistāmība. Verbu un frazeologismu saistāmība. Rīga: LVU, 3-56.

7. Freimane, Inta. 1976. Runāšanas verbu saistāmības īpatnības. P. Stučkas LVU Zinātniskie raksti, 259. sēj. Valodas sistēma. Rīga, 81-106.

8. Freimane, Inta. 1984. Latviešu valodas skaņu verbi. Distributīvais raksturojums. Rīga: LVU.

9. Murāne, Svetlana et al. 2002. Latviešu un krievu valodas skaņu verbu semantiskā valence sastatāmā aspektā. Humanitāro zinātņu vēstnesis, 2. Daugavpils Universitāte: Latgales Kultūras centra izdevniecība, 51-57.

10. Nešpore, Gunta. 2012. Perifērās semantiskās lomas teikumos ar pārvietošanās verbiem. Vārds un tā pētǐšanas aspekti: rakstu krājums, 16 (1). Liepāja: LiePA, 187-196.

11. Silinskij, Stanislav. 1995. Rechevaja variativnost'slova: Na materiale anglijskih imen lica. Sankt-Peterburg: S.-Peterb. gos. un-t.

12. Ul'janov, Jurij. 1988. Latyshsko-russkij associativnyj slovar'. Riga: Zinatne.

13. Vinogradov, Vladimir. 1986. Russkij jazyk. (Grammaticheskoe uchenie o slove). Moskva: Vysshaja shkola. 
14. Zolotova, Galina. 1988. Sintaksicheskij slovar': Repertuar jelementarnyh edinic russkogo sintaksisa. Moskva: Nauka.

\section{Summary}

The choice of a problem for the present research is related to the topicality of investigating the issues of semantic peculiarities and relatedness of speech verbs in Latvian linguistics. Such research was initiated in the 1980 s by the linguist I. Freimane who addressed the importance of making a comprehensive study of speech verbs.

The significant organizing function of verb in the semantic structure of a sentence and the system of language is generally agreed upon. It is often emphasized in linguistics that the semantic structure of verb is characterized by receptivity, broadness, and flexibility that determine the syntactical potencies of verb. The notion of the meaning of verb is inseparable from its ability to connect to other words, besides, words with similar or equal semantics share both common semantic features and typical connection and functionality.

Contemporary linguistics demonstrates particular interest in the issues of verb valence for several reasons. On the one hand, it is related to the formation of lexicalized grammar and complex dictionaries reflecting the valent features of words; on the other, it is grounded by the elaboration of software tools for automatic language analysis and information acquisition.

Special attention is attributed to research that analyses the verb valence in text. In this case, peculiarities of verb valence are located not intuitively and by generalization, but on the basis of concrete usage examples that clearly indicate the determining factors of word valence.

The excerpted Russian-Latvian parallels show that usually in the regarded texts (A. Chekhov's stories and their translations into Latvian) speech verb is modified by a single adverb; Sporadically, speech verbs are related to several adverbs. The produced analysis reveals that the relatedness of speech verbs to an adverb skali ('loudly') is represented in a more emphasized way, that clearly brings out loudness as a pragmatically essential feature of speech. Semantically, adverbs mainly characterize speech verbs with a generalized meaning, thus attributing to the narrative not only notional concreteness but also emotionally expressive connotations. 